\title{
Prevalence of exclusive breastfeeding in the healthy newborn
}

\author{
Pedro Luis del Mazo-Tomé and Marta Suárez-Rodríguez* \\ Servicio de Neonatología. Área de Gestión Clínica de Pediatría, Hospital Universitario Central de Asturias, Asturias, Spain
}

\begin{abstract}
Background: The best nourishment for infants during the first six months of life is exclusive breastfeeding. It is recommended along with other food to complement the diet until the child is two years old, as long as the mother and the child are willing to continue with it. The objectives of this study were to determine the exclusive breastfeeding rate in full-term newborns at hospital discharge and 15 days later and to analyze the factors that positively affect the exclusive breastfeeding. Methods: A prospective study was conducted in which a sample of postpartum women with full-term newborns was recruited during hospital admission. Different variables were compiled, and two interviews were made to determine the kind of feeding they were giving their children and if it was maintained at 15 days of birth. Results: Exclusive breastfeeding rate at hospital discharge is much lower than recommended. It significantly decreases at 15 days of birth, increasing artificial feeding. It seems that a vaginal birth, no complications giving birth, providing early breastfeeding and skin-to-skin contact in the delivery room are predisposing factors necessary to establish good breastfeeding at hospital discharge. Conclusions: Despite the efforts of professionals, the percentage of newborns with exclusive breastfeeding at birth is not enough for the current recommendations.
\end{abstract}

Key words: Breastfeeding. Exclusive breastfeeding. Full-term newborn.

\section{Prevalencia de la alimentación exclusiva con lactancia materna en recién nacidos sanos}

\section{Resumen}

Introducción: El mejor alimento para los niños durante los primeros 6 meses de vida es la lactancia materna exclusiva; se recomienda continuar con el amamantamiento junto con otros alimentos que complementen la alimentación hasta los 2 años o más, mientras madre e hijo lo deseen. Los objetivos de este estudio fueron determinar la tasa de lactancia materna exclusiva en los recién nacidos a término al alta hospitalaria y a los 15 días y analizar los factores que influyen positivamente en la lactancia materna exclusiva. Métodos: Estudio prospectivo en el que se reclutó una muestra de puérperas con hijos a término durante su ingreso. Se recogieron diferentes variables y se realizaron dos entrevistas para determinar el tipo de alimentación que estaban dando a sus hijos y si se mantenía a los 15 días del parto. Resultados: La tasa de lactancia materna exclusiva al alta hospitalaria es muy inferior a lo recomendado. Esta disminuye de manera importante a los 15 días del parto, aumentando la lactancia artificial. Al parecer, el parto eutócico, no presentar complicaciones en el parto, realizar lactancia materna precoz y el contacto piel con piel en el paritorio son factores favorecedores para establecer una buena

\section{Correspondence:}

*Marta Suárez-Rodríguez

Email: msr1070@ hot.com
Available online: 12-07-2018 Bol Med Hosp Infant Mex. 2018;75:46-52 www.bmhim.com 
lactancia materna al alta hospitalaria. Conclusiones: A pesar de los esfuerzos de los profesionales, el porcentaje de recién nacidos alimentados con lactancia materna exclusiva al nacimiento no alcanza las recomendaciones actuales.

Palabras clave: Lactancia materna. Lactancia materna exclusiva. Recién nacido de término.

\section{Introduction}

Breastfeeding $(B F)$ is the source for nourishment for the newborn (NB) due to its clear benefits on neurodevelopment, its immunological, trophic advantages, and the properties of providing the adequate nutritional inputs available at all times. ${ }^{1}$ According to the World Health Organization (WHO) and the American Academy of Pediatrics (AAP), the Breastfeeding Committee of the Spanish Association of Pediatrics (AEP, for its acronym in Spanish) recommends exclusive BF during the first 6 months of the child's life; in addition, the continuation of BF along with other foods that complement the diet until two years or more, as long as the mother and the child so desire. ${ }^{2}$

In Spain, the duration of BF decreased considerably since the $60 \mathrm{~s}$, reaching minimum values in the $70 \mathrm{~s}$. Although in the 90s a discrete increase in the span of $\mathrm{BF}$ began in Spain ${ }^{3}$, currently the percentage of children fed with exclusive or mixed breast milk until three and six months of age is $66.6 \%$ and $46.9 \%$, respectively. ${ }^{4}$

In the Central University Hospital of Asturias (HUCA for its acronym in Spanish) a BF commission has recently been created, which has generated a hospital policy regarding this issue. This paper tries to evaluate if there is an improvement in the rate of exclusive breastfeeding (EBF) after the creation of this commission.

BF has important short and long-term benefits both for the baby who receives it and for the mother who breastfeeds and, indirectly, for society, including advantages of nutritional, immunological, evolutionary, psychological, social, economic and even environmental. ${ }^{2}$

The reduction in the rates of $\mathrm{BF}$ is due, in part, to the health system. Both the care received by the mother during her hospital stay and the characteristics of the place where the delivery takes place are related to the onset and duration of the BF. The lack of support to the mothers that breastfeed, as well as the practices that make it difficult and reduce the mother's milk production, influence the abandonment or failure of $\mathrm{BF}^{5}$

Likewise, the mothers' perception of their aptitude and ability to breastfeed and the way they think they do it, is related to the BF exclusivity and duration. How they see themselves during the process makes mothers decide on a particular type of food or another, which is crucial for achieving successful breastfeeding. ${ }^{6}$
The objectives of this study were to determine the exclusive breastfeeding rate in term newborns at hospital discharge and 15 days later, and to analyze the factors that positively influence exclusive breastfeeding.

\section{Methods}

An analytical and prevalence study was conducted in the obstetrics department of the HUCA, in which groups were compared to seek associations. The HUCA is a third level reference hospital of the Autonomous Community of Asturias, located in the city of Oviedo, Spain, with approximately 2,200 deliveries per year.

\section{Statistical sampling criteria}

TARGET POPULATION Puerperal women of the IV area of Asturias and their NB during the study period. ACCESSIBLE POPULATION Postpartum women of HUCA and their NB during the study period.

ELIGIBLE POPULATION - Inclusion criteria: all healthy puerperal women admitted to the obstetrics plants of HUCA, from December $17^{\text {th }}, 2015$ to January $17^{\text {th }}, 2016$, who gave birth during this period; all puerperal women who wish to participate in the study anonymously and voluntarily; all term newborns (TNB) of the puerperal women who meet the two previous inclusion criteria. - Exclusion criteria: all criteria that are not included in the inclusion criteria, such as postpartum mothers of preterm infants $<36$ weeks of gestational age and those whose NB had to be admitted to the Neonatal Unit for any reason.

For this work, two interviews to the puerperal women were carried out (by the two authors of this work): one on-site during their stay at the hospital within 48 hours after delivery (following an ad hoc questionnaire created for this purpose) and another by telephone 15 days after birth. For the achievement of this second interview, those women who had been discharged with formula feeding (FF) were excluded.

During the first interview, the objective of the study was explained and presented. In case of accepting to participate in it, anonymously and voluntarily, the mother had to sign the informed consent and the information sheet. The interview included different aspects of the NB nutrition: the style of feeding received if the 
mother had decided it before the delivery, number of children, food that the previous children had received, etcetera. Likewise, the mother was informed that she would be contacted by telephone 15 days after delivery to perform the second interview.

The second interview was conducted by telephone to mothers who had planned to give EBF or mixed breastfeeding (MBF) to request information about five issues surrounding the BF process: Do you keep BF? Did you receive help regarding $B F$ during the hospital admission? Would you have liked to have more help regarding feeding the NB during admission? Did you go to the health center $(\mathrm{HC})$ because you needed help with BF? Do you have more children? (and type of BF which they received).

It should be noted that all puerperal women eligible to participate in the study (according to the inclusion criteria), not only wanted to be part of it, but also answered both interviews, so no subject was lost.

In addition to the two interviews, other variables of the mother and the newborn's medical history were collected: age of the mother, gestational age (GA), weight at the beginning and end of the pregnancy, type of delivery, complications in childbirth (urgent caesarean delivery, meconium stained amniotic fluid, need for neonatal resuscitation, moderate-severe hemorrhage of the postpartum mother), date of birth, weight, height and cranial perimeter (CP) at birth, weight at discharge from maternity, Apgar reported at 1 minute and 5 minutes, early BF reception in the delivery room, skin-to-skin contact at birth for more than 60 minutes. The variables EBF, MBF, and FF are defined as follows: EBF receives only breast milk (directly from the breast or by another method, from its mother or another woman), but can receive oral rehydration solutions, drops or syrups (of vitamins, minerals or medicines); the NB does not eat any other food or drink, not even water. As for MBF, the infant receives breast milk, artificial milk (formula adapted according to age) and other foods. Finally, FF is understood as the exclusive nutrition based on artificial milk (formula adapted according to age) and other foods among which breast milk is not included.?

The collected data were analyzed with the statistical program SPSS version 18. The qualitative variables were described using frequencies, and the mean and the standard deviation described the quantitative variables after checking the normality of the variables by the Kolmogorov test. Subsequently, we proceeded to compare the different variables among themselves. The Pearson's chi-squared test was used for the association of qualitative variables to calculate the statistical significance of these comparisons. Throughout the statistical analysis, a limit level of probability significance of $5 \%$ was maintained.
This work has the permission and approval of the Ethics Research Committee of the Autonomous Community of Asturias. In all the work, the international standards of respect and confidentiality on handling anonymous data were followed.

\section{Results}

During the study, there were 171 puerperal women admitted to the maternity unit. Of these, 20 women who had given birth to a premature newborn were excluded, so that the final sample consisted of 151 puerperal women.

\section{Women sample}

The mean age of the women recruited was 33.83 years (standard deviation $(S D)=5.654)$. Of these, $62 \%$ presented a eutocic delivery, $21 \%$ an instrumented vaginal delivery and the remaining $17 \%$ a cesarean delivery. The mean GA was 38.74 (SD = 2.313) weeks; $44 \%$ of the women were multiparous, and $26.8 \%$ had previous abortions. It is worth mentioning that 28 of these women suffered some of the complications previously mentioned in childbirth, which represented $16.4 \%$.

\section{NB sample}

The mean weight at birth was $3,119 \mathrm{~kg}(\mathrm{SD}=0.6)$, while the mean weight at hospital discharge was of $3,053 \mathrm{~kg}(\mathrm{SD}=0.459)$. The mean length at birth was $49.05 \mathrm{~cm}(S D=2.273)$, average $C P$ at birth of $34.08 \mathrm{~cm}$ $(S D=1.863)$, average Apgar score of $8.67(S D=1.347)$ and $9.72(S D=0.868)$ registered at 1 minute and at 5 minutes respectively. The percentage of NB who received early BF within the first hour of life was $73.9 \%$, and $84 \%$ made skin-to-skin contact after the birth of more than 60 minutes.

\section{Feeding at hospital discharge}

The percentage of puerperal women who had decided to breastfeed before delivery was $84.2 \%$; $12.3 \%$ preferred to do it with an adapted formula; the remaining 3.5\% had not made this decision previously. Finally, $58.3 \%$ of the NB left the hospital with EBF, $23.8 \%$ with MBF and $17.9 \%$ with FF (Fig. 1).

\section{Feeding at 15 days}

At 15 days of age, $48.3 \%$ of newborns continued to be fed with EBF, $22.5 \%$ with MBF and $29.1 \%$ with FF (Fig. 1). 


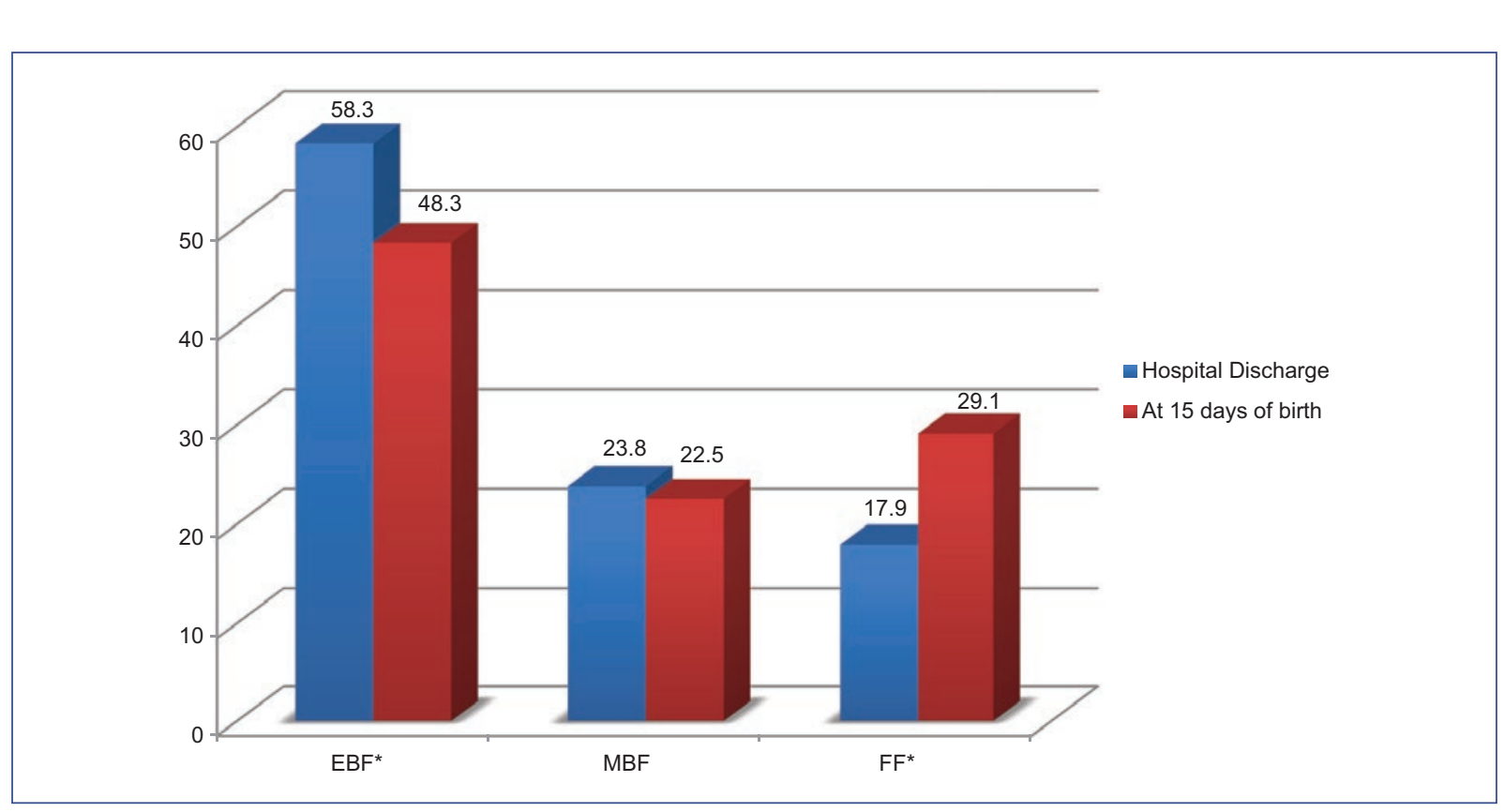

Figure 1. A comparison between the feeding of term newborns at hospital discharge and 15 days of age is observed. EBF: exclusive breastfeeding; MBF: mixed breastfeeding; FF: formula feeding. ${ }^{*}$ Statistically significant difference.

In the interview conducted at 15 days, the 21 women who had decided to feed their children with FF were excluded, as described in the section on methods. Of these 130 women, $56.9 \%$ received support for BF during hospitalization, in contrast to $43.1 \%$ who did not receive it $(68 \%$ of these women would have liked to receive it). Interestingly, $53.8 \%$ would have liked to receive more support on BF, compared to $46.2 \%$ who stated that it would not have been necessary. Finally, $20.8 \%$ of these mothers needed to go to the midwife to their health center to request help about BF, compared to $79.2 \%$, which did not.

When comparing the results obtained from the feeding at hospital discharge with those obtained 15 days later (Fig. 1), it is observed that there are statistically significant differences in those fed by FF, $17.9 \%$ versus $29.1 \%$, respectively. In the same way, there is a statistically significant decrease between the NB fed at birth and 15 days with EBF (58.3\% versus $48.3 \%)$, respectively. There are no differences between those fed at birth and 15 days with MBF.

Regarding the feeding at hospital discharge of the $\mathrm{NB}$, the percentage of women who fed their children with EBF was significantly higher among those who had presented a eutocic delivery, compared with those who had had an instrumental delivery or cesarean (Table 1).
There is also a higher percentage of NB fed with EBF at hospital discharge in the children of mothers who had decided to give EBF before delivery and those who had not suffered complications during the same, these differences being statistically significant (Table 1).

Finally, women who breastfed during the first hour of life of the NB and those who made skin-to-skin contact in the delivery room presented a significantly higher percentage of EBF at hospital discharge than those women who had not been able to perform such practices (Table 1).

Regarding the feeding of children at 15 days of age, higher EBF rates were found in women who had decided to give EBF before delivery, compared to those who had not decided, as well as those who had been able to give early BF, these differences being statistically significant (Table 2).

\section{Discussion}

Many factors influence the type of nutrition that an NB receives, social, cultural and personal. The identification of the specific factor in each case can help support BF individually. The first postpartum week is critical for the establishment of breastfeeding. Hence, in this work, the second interview with the puerpera was carried out in the second week of life, at which time the BF should be well established if desired. 
Table 1. Comparison of qualitative variables as a function of hospital discharge

\begin{tabular}{|c|c|c|c|c|c|}
\hline & & eeding at hospi & & & OR EB \\
\hline & EBF & MBF & FF & $p$ & \\
\hline $\begin{array}{l}\text { Type of delivery } \\
\text { Eutocic } \\
\text { Instrumental } \\
\text { Caesarean section }\end{array}$ & $\begin{array}{c}64 / 96(66.7 \%) \\
21 / 36(58.4 \%) \\
3 / 19(15.8 \%)\end{array}$ & $\begin{array}{l}18 / 96(18.8 \%) \\
10 / 36(27.7 \%) \\
8 / 19(42.1 \%)\end{array}$ & $\begin{array}{l}14 / 96(14.5 \%) \\
5 / 36(13.9 \%) \\
8 / 19(42.1 \%)\end{array}$ & 0.001 & $\begin{array}{c}1 \\
0.7 \\
0.09\end{array}$ \\
\hline $\begin{array}{l}\text { Complications in childbirth } \\
\text { No } \\
\text { Yes }\end{array}$ & $\begin{array}{c}80 / 128(62.5 \%) \\
8 / 23(34.8 \%)\end{array}$ & $\begin{array}{c}29 / 128(22.6 \%) \\
7 / 23(30.4 \%)\end{array}$ & $\begin{array}{c}19 / 128(14.9 \%) \\
8 / 23(34.8 \%)\end{array}$ & 0.025 & 0.32 \\
\hline $\begin{array}{l}\text { Previous abortions } \\
\text { No } \\
\text { Yes }\end{array}$ & $\begin{array}{c}63 / 109(57.8 \%) \\
25 / 42(59.5 \%)\end{array}$ & $\begin{array}{c}23 / 109(21.1 \%) \\
13 / 42(31 \%)\end{array}$ & $\begin{array}{c}23 / 109(21.1 \%) \\
4 / 42(9.5 \%)\end{array}$ & 0.172 & $\frac{1.07}{\frac{10}{\frac{1}{2}}}$ \\
\hline $\begin{array}{l}\text { Has more children } \\
\text { No } \\
\text { Yes }\end{array}$ & $\begin{array}{l}49 / 82(59.8 \%) \\
39 / 69(56.5 \%)\end{array}$ & $\begin{array}{l}22 / 82(26.8 \%) \\
14 / 69(20.3 \%)\end{array}$ & $\begin{array}{l}11 / 82(13.4 \%) \\
16 / 69(23.2 \%)\end{array}$ & 0.254 & $\frac{0.6}{4}$ \\
\hline $\begin{array}{l}\text { Had decided to give BF } \\
\text { No } \\
\text { Yes } \\
\text { Does not know }\end{array}$ & $\begin{array}{c}0 / 21(0 \%) \\
86 / 125(68.8 \%) \\
2 / 5(40 \%)\end{array}$ & $\begin{array}{c}0 / 21(0 \%) \\
36 / 125(28.8 \%) \\
0 / 5(0 \%)\end{array}$ & $\begin{array}{c}21 / 21(100 \%) \\
3 / 125(2.4 \%) \\
3 / 5(60 \%)\end{array}$ & $<0.001$ & $\begin{array}{l}3.3 \\
\frac{\sim}{\varepsilon} \\
\frac{c}{d}\end{array}$ \\
\hline $\begin{array}{l}\text { Had support in the unit } \\
\text { No } \\
\text { Yes }\end{array}$ & $\begin{array}{c}42 / 56(75 \%) \\
46 / 74(62.2 \%)\end{array}$ & $\begin{array}{l}11 / 56(19.6 \%) \\
25 / 74(33.7 \%)\end{array}$ & $\begin{array}{l}3 / 56(5.4 \%) \\
3 / 74(4.1 \%)\end{array}$ & 0.202 & $\frac{0.5}{3}$ \\
\hline $\begin{array}{l}\text { Needed more support } \\
\text { No } \\
\text { Yes }\end{array}$ & $\begin{array}{c}43 / 70(61.4 \%) \\
45 / 60(75 \%)\end{array}$ & $\begin{array}{l}25 / 70(35.7 \%) \\
11 / 60(18.3 \%)\end{array}$ & $\begin{array}{l}2 / 70(2.9 \%) \\
4 / 60(6.7 \%)\end{array}$ & 0.067 & $\begin{array}{l}1.8 \\
\varrho \\
0\end{array}$ \\
\hline $\begin{array}{l}\text { Looked for help in their HC } \\
\text { No } \\
\text { Yes }\end{array}$ & $\begin{array}{l}68 / 103(66 \%) \\
20 / 27(74.1 \%)\end{array}$ & $\begin{array}{c}29 / 103(28.2 \%) \\
7 / 27(25.9 \%)\end{array}$ & $\begin{array}{c}6 / 103(5.8 \%) \\
0 / 27(0 \%)\end{array}$ & 0.403 & $\begin{array}{l}1.4 \\
\frac{1.4}{3} \\
\frac{1}{3}\end{array}$ \\
\hline $\begin{array}{l}\text { Type of feeding in their other } \\
\text { children } \\
\text { No more children } \\
\text { EBF } \\
\text { MBF } \\
\text { FF }\end{array}$ & $\begin{array}{c}48 / 72(66.6 \%) \\
26 / 34(76.5 \%) \\
13 / 20(65 \%) \\
1 / 4(25 \%)\end{array}$ & $\begin{array}{c}21 / 72(29.2 \%) \\
7 / 34(20.6 \%) \\
6 / 20(30 \%) \\
2 / 4(50 \%)\end{array}$ & $\begin{array}{c}3 / 72(4.2 \%) \\
1 / 34(2.9 \%) \\
1 / 20(5 \%) \\
1 / 4(25 \%)\end{array}$ & 0.342 & $\begin{array}{c}0 \\
0.6 \\
1 \\
0.57 \\
0.1\end{array}$ \\
\hline $\begin{array}{l}\text { Early BF } \\
\text { No } \\
\text { Yes }\end{array}$ & $\begin{array}{l}5 / 37(13.5 \%) \\
77 / 104(74 \%)\end{array}$ & $\begin{array}{c}9 / 37(24.3 \%) \\
23 / 104(22.1 \%)\end{array}$ & $\begin{array}{c}23 / 37(62.2 \%) \\
4 / 104(3.9 \%)\end{array}$ & $<0.001$ & $\begin{array}{l}18 \\
\frac{1}{3} \\
\frac{y}{0}\end{array}$ \\
\hline $\begin{array}{l}\text { Skin-to-skin contact } \\
\text { No } \\
\text { Yes }\end{array}$ & $\begin{array}{c}5 / 24(20.8 \%) \\
82 / 125(65.6 \%)\end{array}$ & $\begin{array}{c}9 / 24(37.5 \%) \\
27 / 125(21.6 \%)\end{array}$ & $\begin{array}{c}10 / 24(41.7 \%) \\
16 / 125(12.8 \%)\end{array}$ & $<0.001$ & $\begin{array}{l}7.2 \\
1 \\
0 \\
0\end{array}$ \\
\hline
\end{tabular}

EBF, exclusive breastfeeding; MBF, mixed breastfeeding; FF, formula feeding; OR, odds ratio; HS, health center.

In 2009, the Ministry of Health and Health Services of the Government of the Principality of Asturias carried out a child health survey to obtain data on the prevalence of BF. The sample that was 2,461 cases of children between 0 and 15 years old, obtaining the data retrospectively. ${ }^{8}$ In this study, the prevalence of EBF at seven days after delivery was $59 \%$, decreasing progressively. Thus, it decreased to $57 \%$ at 28 days, $34 \%$ at three months, $27 \%$ at 120 days and $14 \%$ at six months. ${ }^{7}$ These data coincide with those of the present work since there was also a significant decrease in the percentage of children fed with EBF at 15 days of age. Although in this study no data was available beyond this age, it would be expected that the rate of EBF will decrease as the age of the children increases, as stated in this work.

The technical report on BF in Spain, prepared by the CLM of the AEP, established a frequency of BF of $84.2 \%$ at birth, of $77.6 \%$ at one month of life (both values higher than the present results), of $54.9 \%$ at 3 months, and $24.8 \%$ at 6 months of the NB. ${ }^{9}$ It was 
Table 2. Comparison of the qualitative variables according to the feeding at 15 days after delivery.

\begin{tabular}{|c|c|c|c|c|c|}
\hline & \multicolumn{4}{|c|}{ Feeding at 15 days after delivery } & \multirow[t]{2}{*}{ OR EB } \\
\hline & EBF & MBF & FF & $p$ & \\
\hline $\begin{array}{l}\text { Type of delivery } \\
\text { Eutocic } \\
\text { Instrumental } \\
\text { Caesarean section }\end{array}$ & $\begin{array}{l}52 / 96 \\
17 / 36 \\
4 / 19\end{array}$ & $\begin{array}{l}20 / 96 \\
6 / 36 \\
8 / 19\end{array}$ & $\begin{array}{c}24 / 96 \\
13 / 36 \\
7 / 19\end{array}$ & 0.059 & $\begin{array}{l}c \\
\frac{1}{1} \\
0.7 \\
0.2\end{array}$ \\
\hline $\begin{array}{l}\text { Complications in childbirth } \\
\text { No } \\
\text { Yes }\end{array}$ & $\begin{array}{c}62 / 128(48.4 \%) \\
11 / 23(47.8 \%)\end{array}$ & $\begin{array}{c}30 / 128(23.4 \%) \\
4 / 23(17.4 \%)\end{array}$ & $\begin{array}{c}36 / 128(28.2 \%) \\
8 / 23(34.8 \%)\end{array}$ & 0.735 & 0.9 \\
\hline $\begin{array}{l}\text { Previous abortions } \\
\text { No } \\
\text { Yes }\end{array}$ & $\begin{array}{c}52 / 109(47.8 \%) \\
22 / 42(52.4 \%)\end{array}$ & $\begin{array}{c}21 / 109(19.3 \%) \\
13 / 42(30.9 \%)\end{array}$ & $\begin{array}{c}37 / 109(33.9 \%) \\
7 / 42(16.7 \%)\end{array}$ & 0.076 & $\frac{1.2}{\frac{\pi}{\frac{a}{a}}}$ \\
\hline $\begin{array}{l}\text { Has more children } \\
\text { No } \\
\text { Yes }\end{array}$ & $\begin{array}{l}38 / 82(46.4 \%) \\
35 / 69(50.7 \%)\end{array}$ & $\begin{array}{l}22 / 82(26.8 \%) \\
12 / 69(17.4 \%)\end{array}$ & $\begin{array}{l}22 / 82(26.8 \%) \\
22 / 69(31.9 \%)\end{array}$ & 0.375 & $\frac{1.2}{\frac{1}{4}}$ \\
\hline $\begin{array}{l}\text { Has decided to give BF } \\
\text { No } \\
\text { Yes } \\
\text { Does not know }\end{array}$ & $\begin{array}{c}0 / 21(0 \%) \\
72 / 125(57.6 \%) \\
1 / 5(20 \%)\end{array}$ & $\begin{array}{c}0 / 21(0 \%) \\
32 / 125(25.6 \%) \\
2 / 5(40 \%)\end{array}$ & $\begin{array}{c}21 / 21(100 \%) \\
21 / 125(16.8 \%) \\
2 / 5(40 \%)\end{array}$ & $<0.001$ & $\frac{\frac{c}{0}}{\frac{\pi}{5}}$ \\
\hline $\begin{array}{l}\text { Had support in the unit } \\
\text { No } \\
\text { Yes }\end{array}$ & $\begin{array}{l}37 / 56(66.1 \%) \\
36 / 74(48.7 \%)\end{array}$ & $\begin{array}{l}13 / 56(23.2 \%) \\
21 / 74(28.4 \%)\end{array}$ & $\begin{array}{c}6 / 56(10.7 \%) \\
17 / 74(22.9 \%)\end{array}$ & 0.093 & $\begin{array}{l}0.5 \\
\frac{1}{5} \\
\frac{1}{3}\end{array}$ \\
\hline $\begin{array}{l}\text { Needed more support } \\
\text { No } \\
\text { Yes }\end{array}$ & $\begin{array}{c}37 / 70(52.9 \%) \\
36 / 60(60 \%)\end{array}$ & $\begin{array}{c}19 / 70(27.1 \%) \\
15 / 60(25 \%)\end{array}$ & $\begin{array}{c}14 / 70(20 \%) \\
9 / 60(15 \%)\end{array}$ & 0.668 & $\begin{array}{l}1.3 \\
\frac{1}{2} \\
\frac{1}{2}\end{array}$ \\
\hline $\begin{array}{l}\text { Looked for help in their HC } \\
\text { No } \\
\text { Yes }\end{array}$ & $\begin{array}{c}57 / 103(55.4 \%) \\
16 / 27(59.3 \%)\end{array}$ & $\begin{array}{c}26 / 103(25.2 \%) \\
8 / 27(29.6 \%)\end{array}$ & $\begin{array}{c}20 / 103(19.4 \%) \\
3 / 27(11.1 \%)\end{array}$ & 0.592 & $\begin{array}{l}1.1 \\
\frac{c}{ \pm} \\
\frac{z}{3}\end{array}$ \\
\hline $\begin{array}{l}\text { Feeding in their other children } \\
\text { No more children } \\
\text { EBF } \\
\text { MBF } \\
\text { FF }\end{array}$ & $\begin{array}{c}37 / 72(51.4 \%) \\
24 / 34(70.6 \%) \\
10 / 20(50 \%) \\
2 / 4(50 \%)\end{array}$ & $\begin{array}{c}20 / 72(27.8 \%) \\
6 / 34(17.6 \%) \\
8 / 20(40 \%) \\
0 / 4(0 \%)\end{array}$ & $\begin{array}{c}15 / 72(20.8 \%) \\
4 / 34(11.8 \%) \\
2 / 20(10 \%) \\
2 / 4(50 \%)\end{array}$ & 0.155 & $\begin{array}{c}0.44 \\
1 \\
0.4 \\
0.4\end{array}$ \\
\hline $\begin{array}{l}\text { Early BF } \\
\text { No } \\
\text { Yes }\end{array}$ & $\begin{array}{c}8 / 37(21.6 \%) \\
61 / 104(58.7 \%)\end{array}$ & $\begin{array}{c}7 / 37(18.9 \%) \\
22 / 104(21.1 \%)\end{array}$ & $\begin{array}{c}22 / 37(59.5 \%) \\
21 / 104(20.2 \%)\end{array}$ & $<0.001$ & $\begin{array}{l}5.1 \\
0 \\
0 \\
\ddots \\
\ddots\end{array}$ \\
\hline $\begin{array}{l}\text { Skin-to-skin contact } \\
\text { No } \\
\text { Yes }\end{array}$ & $\begin{array}{c}7 / 24(29.2 \%) \\
65 / 125(52 \%)\end{array}$ & $\begin{array}{c}8 / 24(33.3 \%) \\
26 / 125(20.8 \%)\end{array}$ & $\begin{array}{c}9 / 24(37.5 \%) \\
34 / 125(27.2 \%)\end{array}$ & 0.117 & $\begin{array}{l}2.6 \\
\frac{1}{2}\end{array}$ \\
\hline
\end{tabular}

$E B F$, exclusive breastfeeding; MBF, mixed breastfeeding; FF, formula feeding; OR, odds ratio; HS, health center

also found that lactation was significantly shorter in cases in which the GA was less than 37 weeks, in the delivery by caesarean section, and when the birth weight was $<2.5 \mathrm{~kg}$. Most of these data agree with the results observed in this investigation.

The Regional Ministry of Health of Andalucía carried out a study on EBF with children born in the Autonomous Community between June 2003 and June 2004. ${ }^{9}$ Among all the results obtained, it should be noted that $81.6 \%$ of the children were fed with EBF at birth, in contrast to $3.8 \%$ with $\mathrm{MBF}$ and $14.8 \%$ with FF. Atmonth of birth, these figures varied to $63 \%, 10.4 \%$, and $26.6 \%$, respectively. Specifically, the EBF continues to decrease month by month throughout the first year of life. Sacristán-Martín et al..$^{10}$ observed that eutocic delivery is a facilitating factor that influences the onset of EBF, which coincides with the results found in this study.

The percentages of EBF in this work are higher than those published in other studies carried out in the Autonomous Community. However, it is important to 
highlight that they are far from the objectives set by the WHO to achieve exclusive breastfeeding for six months, of at least 12 months together with complementary feeding and up to 2 years if both the mother and the infant want it. Therefore, the strategy that is being carried out in society should be reviewed to favor the maintenance of the EBF as long as possible.

In a study carried out by the Ministry of Health and Health Services of the Principality of Asturias, skin-toskin contact was assessed. They described that $84 \%$ of vaginal births and $42 \%$ of cesarean deliveries maintained it. Moreover, the duration of the skin-to-skin contact was $<30 \mathrm{~min}$ for $74 \%$, between $30-60 \mathrm{~min}$ for $12 \%$ and $>60$ min for $13 \% .^{7}$ In the group studied, higher percentages were observed probably due to the changes that have been gradually introduced into the daily clinical practice of midwives, neonatal nurses, obstetricians, and pediatricians so that skin-to-skin contact is increasingly valued for periods of more than 60 minutes in the delivery room and early BF. In HUCA, skin-to-skin contact is not made with the mother in cesarean deliveries, due to the NB entering the resuscitation units. However, it can be done with the father, if he wishes.

Although ultimately the mother decides to feed her child, breastfeeding - due to its many advantagesmust be an informed decision, and the health staff must explain its benefits beforehand. ${ }^{11}$ It is important to note that in this study, a high percentage of women did not have support for EBF during their hospital admission and a very small percentage asked for help at their health center. Probably, higher rates of BF would be achieved by improving the support of these women during the days following childbirth. In any case, both the data that emerge from this work and those of the published literature indicate that the rates of EBF decrease drastically in the first months of life, for which the health personnel should propose new strategies to support for women who want to feed their children with EBF.

For the improvement of the obtained results, a primary measure in HUCA should be the creation of a job-normally represented by a midwife in other hospitals-in the obstetrics unit dedicated exclusively to report issues and doubts related to BF and to follow up the mothers who have just given birth. In the hospital, this is carried out in a general way by any professional in the unit, be it auxiliary nurse, midwife, supervisor, nurse, doctor, which often generates confusion and contradictory information on this subject. This type of management can lead to doubts, anxiety, errors, and failure in BF. Therefore, it would be very positive if the same person was always in charge of carrying out this task.

\section{Ethical disclosures}

Protection of human and animal subjects. The authors declare that no experiments were performed on humans or animals for this study.

Confidentiality of data. The authors declare that they have followed the protocols of their work center on the publication of patient data.

Right to privacy and informed consent. The authors declare that no patient data appear in this article.

\section{Funding}

None.

\section{Conflicts of interest}

The authors declare no conflicts of interest.

\section{References}

1. Gartner LM, Morton J, Lawrence RA, Naylor AJ, O'Hare D, Schanler LJ, et al. Breastfeeding and the use of human milk. Pediatrics. 2005; 115:496-506.

2. World Health Organization, UNICEF. Global strategy for infant and young child feeding. Geneva: World Health Organization; 2003.

3. Colodro-Conde L, Sánchez-Romero JF, Tornero-Gómez MJ,Pérez-Riquelme $\mathrm{F}$, Polo-Tomás M, Ordoñana JR. The relationship between the level of education and breastfeeding duration depends on social context: breastfeeding trends over a 40 -year period in Spain. $J$ Hum Lact. 2011:27:272-8.

4. Ministerio de Sanidad, Servicios Sociales e Igualdad (MSSSI).Encuesta Nacional de Salud 2011-2012. Available at: http://www.msssi.gob.es/gl/ estadEstudios/estadisticas/sislnfSanSNS/home.html.

5. Division of Child Health and Development: Evidence for the Ten Steps to Successful Breastfeeding. Geneva: World Health Organization, 1999.

6. Dennis CL. Theoretical underpinnings of breastfeeding confidence: a self-efficacy framework. J Hum Lact. 1999;15:195-201.

7. World Health Organization. Indicators for assessing infant and young child feeding practices. Part 1. Definitions. Geneva: World Health Organization; 2008.

8. Gobierno del Principado de Asturias. Consejería de Salud y Servicios Sanitarios. Lactancia materna en Asturias. www.asturias.es.

9. Comité de Lactancia Materna de la AEP. Informe técnico sobre la lactancia materna en España. An Esp Pediatr. 1999;50:333-40.

10. Sacristán Martín AM, Lozano Alonso JE, Gil Costa M, Vega Alonso AT. Situación actual y factores que condicionan la lactancia materna en Castilla y León. Rev Pediatr Aten Primaria. 2011;13:33-46.

11. Zozaya Nieto $C$, Saenz de Pipaon Marcos M. Alimentación del Neonato Normal, Lactancia Materna y Leche de Fórmula, Alimentación del Recién Nacido de Bajo Peso, Alimentación Complementaria, Suplementos Vitamínicos y Minerales. In: Posgrado de experto en asistencia al recién nacido a término. Universidad Católica de Valencia. Sociedad Española de Neonatología (SENeo): Editorial Médica Panamericana; 2009. 